\title{
NOWY KSZTAŁT NAUCZANIA MORALNEGO PAPIEŻA FRANCISZKA A INTUICJE ZAWARTE W TEOLOGII KS. PROF. STANISŁAWA OLEJNIKA
}

Obecny pontyfikat papieża Franciszka spotyka się z dużym zainteresowaniem w świecie i to nie tylko ze strony ludzi wierzących. Papieskie audiencje $\mathrm{i}$ inne spotkania $\mathrm{z}$ wiernymi przyciągają wielu słuchaczy. Dlatego stawia się coraz częściej pytanie: skąd bierze się ta popularność, dlaczego w dobie bardzo czasem daleko posuniętej laicyzacji, a nawet dechrystianizacji papież z Argentyny budzi tyle pozytywnych odczuć i ciągle gromadzi takie thumy ludzi?

Wśród odpowiedzi na tego rodzaju pytania spotyka się najpierw podkreślenia jednej z osobistych cech papież Franciszka łatwo dostrzegalnych już przy pierwszych z nim spotkaniach. Chodzi mianowicie o jego bezpośredniość i bliskość w stosunku do ludzi. Jego wyjątkowa delikatność, a nawet gesty czułości, spontanicznie okazywane każdemu spotkanemu człowiekowi, niewątpliwie są w stanie przełamywać bariery, a nawet dają poczucie bezpieczeństwa. On szanuje i okazuje bliskość każdemu człowiekowi, bez względu na jego pozycję społeczną, czy opinie o nim krążące. Niewątpliwie można w tym dostrzec odwagę bycia człowiekiem i z człowiekiem ${ }^{1}$. Jest nawet postrzegany jako orędownik tych którzy już czy może jeszcze nie wierzą.

\footnotetext{
1 Por. M. Polit i, François parmi les loups, Paryż 2015, s. 82 nn.
} 
Można by jednak zaryzykować wskazanie jeszcze jednego powodu takiej sytuacji w dobie dzisiejszej. Wielu ludzi słucha jego wskazań, także czasami stawiających wysokie wymagania moralne, w świecie oskarżanym o permisywizm w odniesieniu do zasad moralnych, ze względu na jego sposób nauczania moralnego, daleki od moralizmu i wszelkiego moralizatorstwa. Jest on w stanie mówić o trudnych sprawach i wymaganiach moralnych pozbawionych ducha potępienia czy surowych osądów kierowanych pod adresem ludzi. I właśnie ta metoda nauczania moralnego proponowana przez papieża Franciszka, jak się wydaje, zasługuje na szczególną uwagę i pogłębienie.

Wydaje się to być szczególnie aktualnym w tekście złożonym jako wyraz szacunku i pośmiertnego hołdu w tomie poświęconym ks. profesorowi Stanisławowi Olejnikowi, wielkiemu nestorowi, a nawet mentorowi polskiej moralistyki. Jak się wydaje, warto spojrzeć na nauczanie papieża Franciszka poprzez pryzmat publikacji polskiego teologa.

\section{NA NOWO ODKRYĆ ZASADE OIKONOMII JAKO PODSTAWE ANALIZ MORALNYCH}

W piśmiennictwie ks. prof. S. Olejnika, a zwłaszcza w jego wykładach, przewijała się intuicja, że w naszym nauczaniu moralnym musimy na nawo rozpoznać i wykorzystać zasadę oikonomii, szeroko obecną w nauczaniu moralnym Kościoła pierwotnego, zwłaszcza na Wschodzie. Stawało się to jeszcze bardziej wyraźne wobec powtarzającej się refleksji Jana Pawła II o konieczności oddychania Kościoła obydwoma płucami: wschodnim i zachodnim. Moralistykę zachodnią zdominowała zasada epikei, jako rekcji na dążność do „akribeia”, czyli ścisłego zastosowania kanonów kościelnych, także w odniesieniu do konkretnych ludzkich decyzji ${ }^{2}$.

Oparcie się w ocenie moralnej czynu ludzkiego w głównej mierze na epikei znacznie przyczyniło się do jurydyzmu i legalizmu, o które

\footnotetext{
${ }^{2}$ https://translate.google.pl/translate?hl=pl\&sl=en\&u=https://theo.kuleuven. be/apps/doctoraltheses/69/\&prev=search (dostęp z dn. 9.09.2015 r.)
} 
oskarżana jest dzisiaj moralistyka chrześcijańska i to nie tylko przez zwolenników relatywizmu czy permisywizmu moralnego. Właśnie, między innymi z tego powodu, moralność chrześcijańska jest przez wielu, zwłaszcza młodych, odrzucana nawet jeszcze przed jej dokładniejszym poznaniem. Dlatego, nawet najwyższe wartości, mogą nie budzić pragnienia ich zdobywania, a często rodzą dystans czy nawet niechęć w stosunku do nich³.

Oikonomia jako zasada moralna ma charakter teologiczny, w odróżnieniu od przede wszystkim prawnego charakteru epikei. Prowadzi ona do uznania zasady miłosierdzia jako ostatecznego odniesienia dla ludzkich działań, także tych niedoskonałych a nawet złych, podczas gdy epikeia zasadniczo kończy na osiągnięciu sprawiedliwości. Ze względu na Boży plan zbawienia nie możemy poprzestawać jedynie na poziomie sprawiedliwości, ale przekraczając go, trzeba nam koniecznie pójść w kierunku miłości i miłosierdzia ${ }^{4}$. Właśnie ponowne odkrycie zasady oikonomii może znacznie pomóc w przezwyciężeniu odczucia zbytniego legalizmu w chrześcijańskim nauczaniu moralnym.

Praktyka nauczania moralnego papieża Franciszka wyjątkowo koresponduje $\mathrm{z}$ tego rodzaju pojmowaniem wyborów etycznych. I tutaj zasada oikonomii, zwanej także zasadą miłosierdzia, może być bardzo pomocna w poszukiwaniu nowych dróg rozwoju teologii moralnej. Bo jak inaczej zrozumieć wyznanie Franciszka: „Widzę wyraźnie, że rzeczą najbardziej potrzebną dzisiaj Kościołowi jest zdolność do leczenia ran i rozgrzewania serca wiernych, poczucia bliskości. Widzę Kościół jako lazaret po bitwie. Nie ma sensu, aby pytać poważnie rannego w bitwie: czy nie ma zbyt wysokiego poziomu cholesterolu czy cukru we krwi. Musimy leczyć rany. I dopiero wtedy będziemy mogli rozmawiać o innych trudnych sprawach i o wszystkim innym. Goić rany, leczyć rany... Trzeba zaczynać od

3 Por. S. O le j n i k, Teologia moralna fundamentalna, Włocławek 1998, s. $35-36$.

4 Por. A. S p a d e ro, Serce wielkie i otwarte na Boga. Rozmowa z papieżem Franciszkiem, Kraków 2013, s. 59-61. 
rzeczy zupełnie podstawowych. Człowiek musi odczuć miłosierdzie”. Papież przestrzega właśnie przed legalistycznymi dążeniami do moralizmu, a tym bardziej do moralizatorstwa. Moralność ma podnosić słabego człowieka i dawać mu nową nadzieję, pomimo jego słabości i niedoskonałości. Z usta papieża padają bardzo odważne słowa: „, Miłość przed moralnością i dyscypliną suchych zasad"5.

\section{PRZECIWKO MORALIZMOWI W KOŚCIELE}

Papież Franciszek swoimi wypowiedziami wskazuje na nowy sposób widzenia wrażliwości moralnej i priorytetów w wychowaniu moralnym w duszpasterstwie: „Kościół katolicki powinien przestać być obsesyjnie związany z tzw. moralnością antropologiczną: Nie możemy ciągle zajmować się jedynie sprawami związanymi $\mathrm{z}$ aborcją, małżeństwami homoseksualnymi czy stosowaniem metod antykoncepcyjnych. Tak być nie powinno. Ja nie mówiłem wiele na te tematy, tak, że nawet mi to zarzucano.. Ale jeśli o tym mówi, to musimy uwzględniać kontekst. Znamy przecież zdanie Kościoła na ten temat i na podobne sprawy. Jestem synem Kościoła, ale to nie jest konieczne, aby mówić o tym ciągle"6.

Tego typu wypowiedzi papieskie mogą skutecznie podtrzymywać i zachęcać do kontynuowania soborowej odnowy teologii moralnej zaleconej przez Vaticanum II. Papież Franciszek nie tylko do niej zachęca, ale i praktycznie ukazuje, co może ona oznaczać dziś oraz jak bardzo potrzebna jest ciągle współczesnemu Kościołowi. Odwaga

5 «L'amour avant la morale et la discipline». Por. http://www.lavie.fr/religion/catholicisme/pape-francois-1-amour-avant-la-morale-et-la-discipline-19-09-2013-44254_16. php (odczyt dn. 09.09.2015 r.).

6 L'Eglise catholique doit cesser d'être obsédée par la morale anthropologi-

que : "Nous ne pouvons pas seulement prendre position sur les questions liées à l'avortement, au mariage homosexuel et à l'utilisation de méthodes contraceptives. Cela n'est pas possible. Je n'ai pas beaucoup parlé de ces choses, et on me l'a reproché. Mais lorsqu'on en parle, il faut en parler dans un contexte. La pensée de l'Église du reste nous la connaissons et je suis fils de l'Église, mais il n'est pas nécessaire d'en parler en permanence". Por. tamże. 
jego wypowiedzi przyczynia się w niemałym stopniu do tego, ze nie jest zrozumianym, a czasami nawet prowokuje do wypowiadania bardzo krytycznych opinii o jego propozycjach. Nie można jednak nie zauważać faktu, że papież z Argentyny mówi o tym często i do wielu tego typu wątków celowo powraca. Niewątpliwie uznaje nauczanie moralne za cenną część depozytu wiary, który strzeże, ale świadomością, ze nauczanie jest nauczaniem żywym, a nie tylko skarbem szczelnie zamkniętym w dobrze chronionych sejfach. Realizacja Soboru Watykańskiego II co do odnowy teologii, w tym w szczególny sposób teologii moralnej pozostaje ciągle aktualnym zadaniem ${ }^{7}$. Niewątpliwie może to stanowić zachętę, zwłaszcza dla dzisiejszych młodych moralistów poszukujących jeszcze ciągle kształtów swojej drogi twórczej. A wielu z nich to właśnie uczniowie ks. prof. Stanisław Olejnika.

Sam ks. Profesor wpisał się wyraźnie w ten nurt odnowy przez przygotowanie właściwie trzech wersji podręcznika: $W$ odpowiedzi na dar i powołanie Boże. Zarys teologii moralnej, siedmiotomowego Dar - Wezwanie - Odpowiedź oraz ostatniej wersji trzytomowej (Teologii moralnej fundamentalnej, Teologii moralnej życia osobowego i Teologii moralnej życia społecznego). Analizując rozkładanie akcentów w każdym z nich, można zaobserwować coraz bardziej konsekwentne oddalanie się od pokusy moralizowania, przez podkreślanie złożoności rzeczywistości życia moralnego człowieka oraz każdego z etycznych wyborów ${ }^{8}$. W nauczaniu teologii moralnej starał się, aby kazuistyka ustąpiła miejsca Biblii i człowiekowi, aby teologia moralna była żywą dyscypliną wiedzy o Bogu i życiu ludzkim.

Podkreślał często, że nie można zbyt łatwo wydawać osądów moralnych bez uwzględnienia złożoności sytuacji, w jakiej się znalazł

7 Sobór Watykański II, Dekret o formacji kapłańskiej „Optatam totius, nr 16.

8 Por. S. Olejn i k, Wodpowiedzi na dar i powotanie Boże. Zarys teologii moralnej, Warszawa 1979; Tenże, Dar-Wezwanie-Odpowiedź. Teologia moralna, t. I-VII, Warszawa 1987- 1993; Tenże, Teologia moralna fundamentalna, Włocławek 1998; Tenże, Teologia moralna życia osobistego, Włocławek 1999; Tenże, Teologia moralna życia społecznego, Włocławek 2000. 
działający człowiek. Moralista musi czasami zabierać głos w sytuacji, gdy sam nie ma jeszcze do końca sprecyzowanego, jasnego osądu końcowego. Myślenie i przygotowanie do ujęć systemowych, może go otworzyć na dostrzeżenie konieczności zastosowania nowych metod w teologii moralnej, by ustrzec się uproszczeń w podejściu do, czasami bardzo złożonej i trudno poddającej się ocenie moralnej, rzeczywistości życia ludzkiego. I tak na przykład wskazując na aktualność i użyteczność wielu koncepcji scholastycznych w badaniach moralnych, nie sposób pomyśleć dzisiejszego wykładu teologii moralnej, bazując tylko na metodach klasycznych bez otwarcia się na hermeneutykę 9 .

Relacja między Biblią a moralnością i ludzkim działaniem nie polega przede wszystkim na wskazaniu na naśladowanie czy jeszcze mniej na zwykłej transpozycji do czasów i sytuacji dzisiejszych. Polega ona natomiast na przejściu od faktu i słowa zbawienia, których świadkami byli autorzy natchnieni, do sytuacji, które stanowią naszą teraźniejszą rzeczywistość. Zasadą, która leży u samych podstaw możliwości takiego przejścia, jest analogia wiary, która zakłada różnice zewnętrzne w ramach jednak podobieństwa w istocie działania, co pozwala na przeżywanie przez współczesnego człowieka swojej teraźniejszości wobec Boga, teraźniejszości, w której ma dziś podjąć określone działania ${ }^{10}$.

Moralista powinien szukać oświetlenia określonych działań w Biblii, ale nigdy nie zapominając, że te zachowania znajdują swój opis w Piśmie św. i mogą być tylko analogiczne w stosunku do tych, które dotyczą dzisiejszych ludzi. Poza podobieństwem, czasami tylko zewnętrznym, trzeba umieć dostrzec, nieraz bardzo znaczące różnice między jednym i drugim, i nie można się bać ich stwierdzenia. Musi to uświadomić, że oderwane od kontekstu poszczególne perykopy

9 Por. S. S k o b e 1, Humanistyczny wymiar teologii moralnej. Francuska próba odnowy teologii moralnej po Soborze Watykańskim II salezjańskiego teologa Xaviera Thévenot'a, Łódź 2010, s. 90.

10 Por. X. T h é v e n o t, Le discernement éthique. La méthodologie du moraliste catholique, Paris-Association André Robert 1994, s. 10-14. 
biblijne mogą czasami niewiele wnosić do dzisiejszych ocen moralnych. Odwołanie się do metod historyczno-krytycznych wydaje się tutaj konieczne, aby nie twierdzić, że Biblia coś wskazuje, podczas gdy ona nie może tego mówić11. Dlatego nie trzeba oczekiwać identyczności zbioru norm, reguł czy prawa zawartego w Biblii i dzisiejszej moralności. Bardziej będzie chodzić o fundamentalne podobieństwo postaw wobec Boga tamtych świadków przymierza oraz wierzących dzisiaj. Nie trzeba próbować posługiwać się sposobem powtórzenia ze specyficznym cofaniem się wstecz do archetypów przeszłości, ale bardziej korzystać z interpretacji typu paraboli. Chodzi przecież o to, żeby ponownie odkryć, patrząc na analogię sytuacji, podobieństwo ludzkich odniesień. A nie da się dzisiaj tego zrobić bez hermeneutyki, metody tak ważnej i tak często podkreślanej przez naszego autora.

W przeciwnym razie stajemy o krok od moralizatorstwa, tak często popełnianego dziś błędu w praktyce nauczania i wychowania moralnego, błędu, którego skutki niestety, jak się wydaje, nie udało się uniknąć w najnowszej polskiej rzeczywistości, a który skutkuje na naszych oczach coraz większym dystansem, zwłaszcza młodego pokolenia w stosunku do wszelkich autorytetów i wartości przez nich proponowanych ${ }^{12}$.

\section{BUDZIĆ POCZUCIE ODPOWIEDZIALNOŚCI SPOLECZNEJ}

Papież Franciszek podkreśla ideę hierarchii prawd, drogą dla tradycji katolickiej: Prawdy, zarówno dogmatyczne jak i moralne, nie są równoważne. Duszpasterstwo charakterze misyjnym, a tak je właśnie pojmuje, nie może mieć obsesji na punkcie przekazywania jak największej ilości doktryn, które mają być wymuszone i to w trybie pilnym. Głoszenie typu misyjnego powinno się skupiać na kwestiach zasadniczych, na tym, co konieczne, co jednocześnie

\footnotetext{
11 Por. P. R i c o e u r, Le conflit des interprétations. Essais d herméneutique, Paris-Seuil 1979, s. 178.

12 Por. S. O l e j n i k, Teologia moralna fundamentalna, dz. cyt., s. 309-310.
} 
wzbudza najwięcej zaangażowanie i pociąga najbardziej, co sprawia, że serce płonie, podobnie jak u uczniów z Emaus. Musimy więc znaleźć nową równowagę, inaczej moralny gmach Kościoła ryzykuje, że się rozpadnie jak domek z kart, tracąc świeżość i zapach Ewangelii. Przesłanie Ewangelii musi być proste, głębokie, promienne. To właśnie jedynie $\mathrm{z}$ takiego głoszenia, mogą wypływać następnie konsekwencje moralne zarówno w wymiarze życia osobistego, jaki i życia społecznego człowieka ${ }^{13}$.

To wskazanie zdaje się być bardzo aktualnym we współczesnym życiu chrześcijanina, ale i patrząc szerzej w całym życiu społecznym. Ogólnie znane i powszechne akceptowane, nie tylko przez ludzi wierzących, jest zainteresowanie, a jeszcze bardziej zaangażowanie papieża Franciszka w odniesieniu do spraw społecznych. Podkreśla się, że papież Franciszek jest nie tylko znawcą tych spraw, co da się zrozumieć patrząc na przebieg jego życia, zwłaszcza na okres posługiwania w trudnej i złożonej sytuacji społecznej w diecezji Buenos Aires w Argentynie, ale przede wszystkim akceptowany jest fakt jego praktycznego autentycznego zaangażowania w rozwiązywanie czasami bardzo trudnych spraw i zachęcanie do takiego zaangażowania innych. Z całą pewnością można już dzisiaj mówić o Franciszku jako o papieżu spraw społecznych. To chrześcijańskie „społeczne” świadectwo życia obecnego papieża zdaje się coraz mocniej pociągać i angażować nie tylko samych chrześcijan ${ }^{14}$. To papieskie zaangażowanie społeczne ostatnio przybrało kształt encykliki Laudato si', poświęconej kwestii ekologicznej, a która wzbudziła zainteresowanie w całym świecie, nawet daleko poza chrześcijaństwem czy katolicyzmem.

Zarówno w pracach badawczych, jak i w całym dorobku naukowym ks. prof. S. Olejnika można dostrzec coraz większe zainteresowanie

13 Por. http://www.lavie.fr/religion/catholicisme/pape-francois-l-amour-avant-la-morale-et-la-discipline-19-09-2013-44254_16.php (dostęp dn. 09.09. 2015 r.)

${ }_{14}$ Por. H. Wa $1 \mathrm{~d}$ e $\mathrm{n} \mathrm{fe} \mathrm{ls}$, Na imię mu Franciszek. Papież ubogich, Poznań 2014, s. 27nn. Por. także, S. S k o b e 1, Papiez Franciszek „Laudato si”-w drodze ku ekologii integralnej, „Społeczeństwo”, (2015) nr 1-2, s. 26. 
i zaangażowanie w wyjaśnianie spraw społecznych, zwłaszcza od strony moralnej. W jego długim życiu twórczym narastała świadomość konieczności budowania świadomości społecznej wśród chrześcijan, a zwłaszcza ukazywania kwestii odpowiedzialności moralnej nie tylko w zakresie życia osobowego, ale i społecznego. Bycie Kościołem jako wspólnotą zbawionych przez Chrystusa, pociąga za sobą konieczność budowania wszelkich ludzkich społeczności na wzór ewangeliczny w przekonaniu, ze jest to najdoskonalszy model, budowany według słów apostoła narodów ,jedni drugich brzemiona noście"15. W kolejnych podręcznikach teologii moralnej, w częściach dotyczących życia społecznego widać coraz większą troskę autora o coraz bardziej dogłębną argumentację wszelkich norm dotyczących wyborów człowieka, mających wpływ czy wprost dotykających relacji międzyludzkich. To samo dotyczy jasności przekazu takich treści. W niemałej mierze można by powiedzieć, że wskazania te przekraczają granice konfesyjności, a przybierają charakter norm ogólnoludzkich. Zarówno u papieża Franciszka jak i u naszego Profesora widać tu przekonanie, ze właściwe postrzeganie swojej roli we wspólnocie pozwala dzisiejszemu człowiekowi uniknąć poczucia absurdu, na który czasy dzisiejsze mogą wielorako narażać.

„Moralność to ostatecznie to, do czego ludzkość się zobowiązuje, kiedy chce nadać sens swojemu życiu, co uzdalnia ostatecznie do przeciwstawienia się presji absurdu". Tak więc do pragnienia szczęścia, które jest naturalnym pragnieniem człowieka, dochodzi w pojęciu moralności i teologii to, do czego człowiek sam się zobowiązuje, by nie utracić sensu swej egzystencji ${ }^{16}$. Nie chodzi tylko o wewnętrzną spójność samego człowieka, ale o to, by komunikacja i relacje międzyludzkie nie zostały unicestwione wobec ciągłego zmagania się czy przynajmniej ocierania się o to, co nosi znamiona bezsensu i absurdu. To właśnie tutaj trzeba przywołać wagę i znaczenie cnót teologicznych wiary i nadziei, które dotykają nas dzięki

15 Gal 6, 2.

16 Por. X. Th é ve n o t, Une éthique au risque de l'Evangile, Desclée de Brouwer - Éd. Du Cerf, Paryż 1993, s. 18-19. 
łasce Boga, udzielonej szczególnie w Jezusie Chrystusie. Poszukiwanie sensu odbywa się nie ze względu na zniewalające zewnętrznie zobowiązanie, ale przez płynące $\mathrm{z}$ wewnętrznej potrzeby pragnienie, będące manifestacją wolności wewnętrznej człowieka prowadzące ostatecznie do miłości ${ }^{17}$.

\section{KU TEOLOGII DUCHOWOŚCI}

Nietrudno zauważyć, że papież Franciszek, pomimo swoich licznych zaangażowań zewnętrznych i społecznych, zachwyca swoją niemal dziecięca wiarą oraz całkowitym oddaniem i wewnętrznym zjednoczeniem z Bogiem. Jego delikatność i takt, z jakimi się odnosi do każdego człowieka, ma swoje zakorzenienie w jego głębokiej relacji z Bogiem. Wielu podkreśla, ze odznacza się on prawdziwą osobowością mistyczną, czym daje prawdziwe świadectwo życia chrześcijańskiego i wielkiego religijnego zaangażowania duchowego. W wielu jego wypowiedziach nie sposób nawet oddzielić wskazówek dotyczących przemian strukturalnych, koniecznych w lansowanej przez niego reformie Kościoła, od najbardziej duchowych i intymnych jego odniesień do Boga. W tym chyba także należy szukać klucza do skuteczności jego nauczania moralnego. Pełna jedność jego sylwetki moralnej i duchowej staje się godnym podziwu wzorem dla dzisiejszych chrześcijan. Wydaje się, że papież Franciszek uważa nawet duchowość za praktykę moralności. W swoich przemówieniach przestrzega nawet przed zbytnim teoretyzowaniem w zakresie moralności. Zachęcał swoich słuchaczy do podejmowania prób skonkretyzowania wysiłków moralnych na płaszczyźnie duchowości chrześcijańskiej.

Widać dzisiaj wyraźne ożywienie w zakresie poszukiwania duchowości. Wyodrębnienie się teologii duchowości jako samodzielnej dyscypliny teologicznej można uważać za konkretną odpowiedź na dwa zjawiska obserwowane w Kościele i w świecie. Paradoksalnie wzrostowi niewiary i obojętności religijnej w naszych czasach

17 Por. S. Olej n i k, Dar - Wezwanie - Odpowiedź. Teologia moralna, t. V, Warszawa 1991, s. 204-214. 
towarzyszy nowe odkrycie oraz rozwijające się w wielu ludziach pragnienie duchowości. Materializm i konsumpcjonizm nie były w stanie zaspokoić najgłębszych ludzkich pragnień. Czasami to poszukiwanie rzeczywistości duchowej przybierało postać bardziej intuicyjną niż pogłębioną świadomą refleksją. Burzliwy rozwój wszelkich poszukiwań ezoterycznych jest tego bardzo wyraźnym dowodem. Stąd w Kościele coraz częściej pojawiały się sugestie wydzielenia odrębnej dziedziny, która byłaby w stanie odpowiedzieć przynajmniej częściowo na tego rodzaju zapotrzebowania. Z drugiej strony pojawiła się w teologii niekorzystna tendencja podziału na moralność, ascetykę i mistykę, co w praktyce przyczyniło się do rozdziału między moralnością i duchowością. Teologii duchowości stawiano za zadanie zasypanie tej istniejącej już przepaści ${ }^{18}$.

I tutaj warto zauważyć ogromną intuicję śp. ks. prof. Olejnika ujawnioną już wiele lat wcześniej. Prowadząc bogatą działalność naukową z zakresu etyki filozoficznej i teologii moralnej, zainicjował w Akademii Teologii Katolickiej teologię duchowości chrześcijańskiej jako odrębny kierunek studiów. Sam czuwał nad rozwojem tej dziedziny i w swoich publikacjach wykazywał ścisły związek teologii moralnej z teologią dachowości, uważając właśnie duchowość za praktykę moralności chrześcijańskiej. Nie jest bowiem możliwe określenie chrześcijańskiej duchowości w sposób czysto negatywny (unikać grzechu), bez jej poważnego okaleczenia.

Dążenie do doskonałości jest treścią chrześcijańskiego życia, a nie tylko jedną z dowolnych opcji. Nie można oddzielać sfery rozumu (dogmatycznej i moralnej) od sfery uczuć (postrzeganych jako doznania przynajmniej podejrzane), bez niebezpiecznego podważenia jedności między wypełnianiem obowiązku i poszukiwaniem szczęścia. Prowadzi to bowiem do zapomnienia, że powołaniem wszystkich chrześcijan jest szczęście - z racji zjednoczenia z Bogiem. Życie duchowe całkowicie oderwane od treści wiary staje się

18 Por. S. S k o b e 1, Humanistyczny wymiar teologii moralnej, dz. cyt., s. 178-179. 
jedynie subiektywną egzaltacją. Nie można oddzielić duchowości od moralnego obowiązku i od objawionej prawdy ${ }^{19}$.

Spuścizna pisarska nestora polskich moralistów śp. ks. profesora Stanisława Olejnika niewątpliwie wpisała na trwałe w historię polskiej moralistyki i ciągle pozostaje ważnym punktem odniesienia dla dzisiejszych badań. Dlatego tym bardziej warto sobie uświadomić jej aktualność w zestawieniu z wyjątkowym i coraz bardziej zadziwiającym pontyfikatem obecnego papieża Franciszka.

\section{New Form of Moral Teaching of Pope Francis and the Intuitions Contained in the Theology of F. Professor Stanisław Olejnik Summary}

Moral Theology of F. prof. Stanislaus Olejnik inscribed permanently into the achievements of Polish moralizing. Although much has already been created years ago, it turns out to be very current today. This is evident in comparison with the pontificate of Pope Francis and his method of teaching morality.. Scientific intuitions of this famous Polish moralist may be an inspiration for the work of contemporary researchers. Especially clearly this can be seen in terms of a new approach to methods of teaching about morality, at the level of social morality and spirituality as a practice of the moral life. Let the many Polish moralists, following the example of his teachers, they develop his insights and make it more current.

\section{Bibliografia:}

Papież Franciszek, Encyklika Fidei Lumen, Warszawa 2014.

Papież Franciszek Adhortacja apostolska Evangelii Gaudium, Kraków 2014.

Papież Franciszek, Encyklika Laudato Si', Kraków 2015.

Papież Franciszek - kard. Jorge Mario Bergoglio, Chciałbym Kościoła ubogiego i dla ubogich, Kraków 2014.

19 Za przykład może tutaj posłużyć cały tom IV podręcznika siedmiotomowego. Por. S. O le j n i k, Dar - Wezwanie - Odpowiedź. Teologia moralna, Warszawa 1989. 
Olejnik S., Dar - Wezwanie - Odpowiedź. Teologia moralna, t. I-VII, Warszawa $1987-1993$.

Olejnik S., Teologia moralna fundamentalna, Włocławek 1998.

Olejnik S., Teologia moralna życia osobistego, Włocławek 1999.

Olejnik S., Teologia moralna życia społecznego, Włocławek 2000.

Olejnik S., W odpowiedzi na dar i powołanie Boże. Zarys teologii moralnej, Warszawa 1979.

Politi M., François parmi les loups, Paryż, 2015.

Ricoeur P., Le conflit des interprétations. Essais d herméneutique, Paris-Seuil 1979.

Scalferi E., Papież Franciszek - rozmowy z niewierzacymi, Kraków 2013.

Spadero A., Serce wielkie i otwarte na Boga. Rozmowa z papieżem Franciszkiem, Kraków 2013.

Thévenot X., Le discernement éthique. La méthodologie du moraliste catholique, Paris-Association André Robert 1994.

Thévenot X., Une éthique au risque de l'Evangile, Desclée de Brouwer - Éd. Du Cerf, Paryż 1993.

Waldenfels H., Na imię mu Franciszek. Papież ubogich, Poznań 2014. 